\title{
Genetic analysis of resistance to flower bud thrips (Megalurothrips sjostedti) in cowpea (Vigna unguiculata [L.] Walp.)
}

\author{
E. E. Omo-Ikerodah · C. A. Fatokun • \\ I. Fawole
}

Received: 17 April 2008/ Accepted: 9 July 2008/Published online: 31 July 2008

(C) The Author(s) 2008

\begin{abstract}
Cowpea is an important legume in subSaharan Africa where its protein rich grains are consumed. Insect pests constitute a major constraint to cowpea production. Flower bud thrips (FTh) is the first major pest of cowpea at the reproductive stage and if not controlled with insecticides is capable of reducing grain yield significantly. Information on the inheritance of resistance to FTh is required to facilitate breeding of resistant cultivars. The genetics of resistance was studied in crosses of four cowpea lines. Maternal effect was implicated while frequency distributions of the $F_{2}$ and backcross generations suggest quantitative inheritance. Additive, dominance and epistatic gene effects made large contributions and since improved inbred lines are the desired product, selection should not be too severe in the early generations to allow for desirable gene recombination. This study suggested that some of the genes involved in the control of resistance to FTh are different in TVu1509 and Sanzi. Broad sense heritability ranged from $56 \%$ to $73 \%$. Choice of maternal parent in a cross will be critical to the success of resistance breeding.
\end{abstract}

E. E. Omo-Ikerodah $(\bowtie) \cdot$ C. A. Fatokun

International Institute of Tropical Agriculture, Ibadan, Nigeria

e-mail: e.omo-ikerodah@yahoo.com

E. E. Omo-Ikerodah · I. Fawole

Department of Crop Protection and Environmental

Biology, University of Ibadan, Ibadan, Nigeria
Keywords Frequency distribution .

Gene effects - Generation means analysis ·

Megalurothrips sjostedti . Quantitative resistance . Vigna unguiculata (L.) Walp.

\section{Introduction}

Cowpea (Vigna unguiculata [L.] Walp.) is one of the world's most important food legume crops. With about $25 \%$ protein in its grains, cowpea is an important source of quality nourishment to the urban and rural poor of West Africa who cannot afford meat and milk products. Cowpea leaves are used as vegetables especially in East Africa and the haulms, which contain over $15 \%$ protein constitute a valuable source of high quality fodder for livestock. Despite its importance, cowpea faces numerous production constraints. Insect pests, plant diseases, parasitic flowering plants and drought are major yield-reducing factors (Terao et al. 1997). The low yields become more striking when it is realized that the average yield of cowpea in West and Central Africa is about 0.24 t/ha (Quin 1997) in spite of the fact that there are a number of cowpea lines that with proper management, can yield above 2.0 t/ha (Duke 1990; Singh et al. 1997).

Flower bud thrips (FTh), Megalurothrips sjostedti, is a major pest of cowpea that causes considerable grain yield losses. The yield reduction due to FTh ranges from 20 to $80 \%$ but under severe infestation, grain 
yield may be almost nil (Singh and Allen 1980). Chemical control measures have been used and are the most widely known form of control of this pest in cowpea. Traditional cowpea growers in Africa do not habitually use insecticides, as reflected in the poor yields they obtain. However, a 10-fold increase in grain yield has been demonstrated with the use of insecticides (Afun et al. 1991). Currently, economic realities and public sensitivity to environmental degradation have rendered extensive insecticide use unacceptable. Therefore, concerted efforts are being made to develop varieties of cowpea that are resistant to insect pests to minimise the need for chemical use. Although there is evidence that low levels of resistance to FTh exists in some cowpea varieties, the desired levels of resistance have not been identified or obtained among available cowpea landraces and improved varieties. A low level of resistance to this insect was reported in the cowpea accession, TVu 1509. The genes for thrips resistance in TVu 1509 have been transferred to some other improved cowpea breeding lines. A landrace, Sanzi, from Ghana has been identified with a moderately high level of resistance to FTh. It is desirable to determine whether the genes for resistance in Sanzi differ from those in $\mathrm{TVu}$ 1509. If the genes are different, it is conceivable that they can be accumulated in a cowpea variety with good genetic background. Higher levels of resistance to this pest are desirable because under heavy infestation, lines with low levels of resistance succumb.

Preliminary studies at International Institute of Tropical Agriculture (IITA 1983) speculated that two recessive genes control resistance to flower bud thrips. However, in the screening for resistance to FTh in cowpea (Jackai and Singh 1988), continuous distributions of phenotypes ranging from very susceptible to resistant were observed. This suggests that the inheritance of FTh resistance is probably quantitative. The objective of this study therefore was to investigate the mode of inheritance of resistance to FTh in cowpea.

\section{Materials and methods}

The experiments were conducted during the second growing seasons (September to November) of 1998 and 1999 under greenhouse and field conditions at the IITA, main station, Ibadan, Nigeria. Ibadan is located at $7^{\circ} 30^{\prime} \mathrm{N}$ and $3^{\circ} 54^{\prime} \mathrm{E}$, at $213 \mathrm{~m}$ altitude.
Two cowpea genotypes, TVu 1509 and Sanzi that have been identified as possessing some levels of resistance to thrips (Singh 1977; C. A. Fatokun, personal communications) and two susceptible cultivars, VITA 7 and Ife Brown were used as test materials. VITA 7 is a cowpea line at IITA. TVu 1509 and Ife Brown are germplasm line and cultivar, respectively, developed at Obafemi Awolowo University, Ile-Ife. Sanzi is a landrace from Ghana and has been identified with moderately high resistance to FTh.

The four cowpea lines were planted in a randomized complete block design with four replicates in the field during the second planting season, August to November 1999 under rain-fed conditions. Each line was planted on a 4-row plot. Each row was $4 \mathrm{~m}$ long with inter row spacing of $0.75 \mathrm{~m}$ and plant-to-plant distance of $0.2 \mathrm{~m}$ within a row, giving a population density of 6,667 plants per hectare. The experiment was given full protection by spraying with the insecticide Sherpa plusR, Cypermethrin + Dimethoate, 35 days after planting and subsequently at 8-day intervals. Agronomic characteristics such as number of days after planting to $50 \%$ flowering, number of days from planting to maturity (when $50 \%$ of the plants had ripe pods), growth habit, average number of pods per plant, average number of seeds per pods, average pod length (cm) and average 100-seed weight (g) were measured.

Resistance of cowpea genotypes

to Megalurothrips sjostedti

The field experiment was conducted during the second growing season i.e. August to November, 1999. The four lines were planted out in the field in a randomised complete block design as described above but in this experiment no form of protection against thrips or other insects was given. Data were collected on day to first flower opening (DFF), thrips damage rating (Jackai and Singh 1988), number of pods per plant and number of thrips per flower.

\section{Resistance to M. sjostedti in cowpea}

In order to study cowpea resistance to $M$. sjostedti two FTh-susceptible and two FTh-resistant lines were crossed in all possible combinations to produce $F_{1}$ plants and their reciprocals. The $\mathrm{F}_{1}$ plants were selfed to produce $F_{2}$ progenies and at the same time backcrossed to their respective parents. For each cross, 
six generations, $\mathrm{P}_{1}, \mathrm{P}_{2}, \mathrm{~F}_{1}, \mathrm{~F}_{2}, \mathrm{BCP}_{1}$, and $\mathrm{BCP}_{2}$, were produced in the greenhouse and were planted in the field at Ibadan in September of 1998 when there was natural infestation of thrips. All materials were grown in a randomized complete block design with three replications. Each replicate contained one plot of each of the parents, $\mathrm{F}_{1}$ and $\mathrm{RF}_{1}$, two plots of each backcross and six plots of each $\mathrm{F}_{2}$ and $\mathrm{RF}_{2}$ generations. Each plot was made up of a row, $4 \mathrm{~m}$ long with $0.75 \mathrm{~m}$ between rows. Plant-to-plant distance was $0.20 \mathrm{~m}$ giving $18-20$ plants per row. Although there was an infestation of a complex of insects, no insecticide was applied since FTh is a major pest of cowpea at flowering and FTh infestation determines whether pods will form or not. Damage rating of all the plants was carried out as described by Jackai and Singh (1988). Other parameters recorded include days to first flower opening (DFF) and number of pods produced per plant. The damage rating was used to classify the plants into different resistance classes. Generation mean analysis was utilized for estimating genetic parameters.

\section{Screening of cowpea for resistance to FTh}

To ensure high populations of thrips, the cowpea lines were planted in a plot located near an established field of pigeon pea, which was a source of inoculum of thrips. Thrips are normally attracted to the pigeon pea flowers where their population remains high. Susceptible spreader rows of VITA 7 were also planted around the plot and between rows two weeks prior to planting of test lines. Thirty-five days after planting, the spreader row plants (VITA 7) were uprooted and laid down between rows of test plants. Test plants were rated for damage on a scale of 1-9 at about 37 days after planting, and subsequently at weekly intervals until pods matured as described by Jackai and Singh (1988). Rating was based on a combination of varying intensities of browning of the stipules and flower buds, nonelongation of peduncles and flower bud abscission.

\section{Data analyses}

Analysis of variance for key parameters of the parental lines was conducted to check whether the genotypic variation was significant prior to conducting genetic analysis using the general linear model (GLM) procedure of the Statistical Analysis System (SAS) programme. Generation mean analysis (GMA) was used to measure genetic parameters following the procedure described by Kang (1994). Generation means were calculated for each of the 6 generations on an individual plant basis. To determine the mode of inheritance of resistance to FTh, Gamble's (1962) notation was used, where $\mathrm{m}=\mathrm{F}_{2}$ mean, $\mathrm{a}=$ additive gene effects, $\mathrm{d}=$ dominance gene effects, aa $=$ additive $\times$ additive epistatic gene effects, ad $=$ additive $\times$ dominance epistatic gene effects and dd $=$ dominance $\times$ dominance epistatic gene effects. The model for a generation mean, $\mathrm{Y}$, is:

$\mathrm{Y}=\mathrm{m}+\alpha \mathrm{a}+\beta \mathrm{d}+\alpha 2 \mathrm{aa}+2 \alpha \beta \mathrm{ad}+\beta 2 \mathrm{dd}$.

where Y, the observed generation mean; $\mathrm{m}, \mathrm{F} 2$ mean; a, additive gene effects; d, dominance gene effects; aa, additive $\times$ additive epistatic gene effects; ad, additive $\times$ dominance epistatic gene effects and $\mathrm{dd}$, dominance $\times$ dominance epistatic gene effects. $\alpha$ and $\beta$ represent the coefficients for the genetic effects for the particular generation being estimated (Hayman 1958; Mather and Jinks 1982).

Correlation analysis was used to investigate the relationship between FTh damage rating and number of mature pods produced per plant and other agronomic traits measured in the parental lines and $\mathrm{F}_{2}$ populations.

Broad sense heritability for resistance to FTh was calculated from the genetic components using the formulae of Mahmud and Kramer (1951).

Broad sense heritability $\left(\mathrm{H}_{\mathrm{bs}}\right)=\mathrm{V}_{\mathrm{F} 2}-\mathrm{V}_{\mathrm{E}} / \mathrm{V}_{\mathrm{F} 2}$ where $V_{F 2}, F_{2}$ variance; $V_{E}$, environmental variance.

The following formula proposed by Lawrence and Frey (1976) was used to estimate the minimum number of effective factors $(\mathrm{N})$

$\mathrm{N}=\mathrm{R}^{2} / 8 \sigma^{2} \mathrm{~g}$,

where $\mathrm{R}$, range of the $\mathrm{F}_{2}$ segregates in the cross and $\sigma^{2} \mathrm{~g}$ is the genetic variance.

Paired $t$-test analysis was carried out on F1 and RF1 means to determine possible reciprocal differences.

\section{Results}

The agronomic characteristics of the parents used in this study are presented in Table 1 . The average number of pods produced per plant was drastically reduced by thrips infestation (Table 2). Mean yield 
Table 1 Agronomic characteristics of cowpea varieties used in the experiments under full protection of plants

\begin{tabular}{lllllllll}
\hline Variety & $\begin{array}{l}\text { Mean no. of } \\
\text { pods produced } \\
\text { per plant }\end{array}$ & $\begin{array}{l}\text { Mean pod } \\
\text { length }(\mathrm{cm})\end{array}$ & $\begin{array}{l}\text { Mean no. of } \\
\text { seeds per pod }\end{array}$ & $\begin{array}{l}\text { Yield per plant } \\
(\mathrm{g})\end{array}$ & $\begin{array}{l}\text { Flower } \\
\text { colour }\end{array}$ & $\begin{array}{l}\text { Days to } \\
50 \% \\
\text { flowering }\end{array}$ & $\begin{array}{l}\text { Days to } \\
50 \% \\
\text { maturity }\end{array}$ & $\begin{array}{l}\text { Growth } \\
\text { habit }\end{array}$ \\
\hline Ife Brown & $22.45 \pm 2.35$ & $12.74 \pm 0.19$ & $10.56 \pm 0.37$ & $37.26 \pm 5.24$ & $\begin{array}{l}\text { Light purple/ } \\
\text { Yellow }\end{array}$ & 42 \pm 0.41 & $71 \pm 0.75$ & Semi-erect \\
& & & & & & \\
Sanzi & $18.59 \pm 1.39$ & $13.36 \pm 0.09$ & $13.06 \pm 0.21$ & $21.85 \pm 1.70$ & Purple & $41 \pm 0.48$ & $61 \pm 0.48$ & Prostrate \\
TVu1509 & $18.32 \pm 0.42$ & $11.84 \pm 0.22$ & $14.07 \pm 0.26$ & $16.08 \pm 1.19$ & White & $41 \pm 0.41$ & $60 \pm 0.48$ & Erect \\
VITA 7 & $14.39 \pm 0.31$ & $14.87 \pm 0.22$ & $13.23 \pm 0.28$ & $25.22 \pm 0.89$ & Purple & $42 \pm 0.00$ & $61 \pm 0.25$ & Erect \\
\hline
\end{tabular}

Table 2 Mean number $( \pm \mathrm{SE})$ of pods produced per plant, days to first flower opening, percentage yield reduction and damage rating for four cowpea varieties $(n=20)$ under insecticide protection and no protection

\begin{tabular}{|c|c|c|c|c|c|}
\hline \multirow[t]{2}{*}{ Variety } & \multicolumn{2}{|c|}{ Mean number of pods produced per plant } & \multirow{2}{*}{$\begin{array}{l}\% \text { Yield } \\
\text { reduction }\end{array}$} & \multirow{2}{*}{$\begin{array}{l}\text { Mean number of days } \\
\text { to } 50 \% \text { flowering }\end{array}$} & \multirow[t]{2}{*}{ Mean damage rating* } \\
\hline & Protected & No protection & & & \\
\hline Ife Brown & $22.45 \pm 2.36$ & $0.86 \pm 0.19$ & 96.00 & $42.34 \pm 0.74$ & $7.99 \pm 0.11 \mathrm{a}$ \\
\hline Sanzi & $18.59 \pm 1.39$ & $5.16 \pm 1.18$ & 72.24 & $41.48 \pm 0.44$ & $4.25 \pm 0.23 c$ \\
\hline TVu 1509 & $18.32 \pm 0.42$ & $3.65 \pm 0.58$ & 80.00 & $41.51 \pm 0.48$ & $5.60 \pm 0.25 b$ \\
\hline VITA 7 & $14.39 \pm 0.31$ & $0.94 \pm 0.25$ & 93.00 & $42.67 \pm 0.18$ & $7.44 \pm 0.15 a$ \\
\hline
\end{tabular}

* Means followed by the same alphabet are not significantly different from each other

loss due to pest attack was $84 \%$ with the highest yield loss of $96 \%$ in Ife Brown. These values did not however take into consideration the confounding effects of other cowpea insect pests.

There were significant differences in the responses of the four genotypes to thrips infestation (Table 2). The mean thrips damage rating and average number of pods per plant showed Sanzi to be resistant and TVu 1509 to be moderately resistant while Ife Brown and VITA 7 were classed as susceptible. Average thrips damage rating was positively correlated with average number of days to first flower opening ( $r=0.58, P<0.01)$ but negatively correlated with average number of pods produced per plant $(r=$ $-0.675, P<0$. 01) (Table 2).

Genetics of cowpea resistance to $M$. sjostedti

\section{Reciprocal effect}

In the $\mathrm{F}_{1}$ generation, reciprocal differences were observed in the crosses $(P<0.01)$ (Table 3$)$. The result from the reciprocal crosses consistently showed that the use of the resistant parents (Sanzi and TVu 1509) as female parent produced progenies with better resistance than when used as male parent.
Table 3 Mean flower bud thrips damage scores $( \pm S E)$ of five cowpea reciprocal crosses for $F_{1}$ generation

\begin{tabular}{llll}
\hline Cross $^{\mathrm{a}}$ & $\mathrm{F}_{1}$ & $\mathrm{RF}_{1}$ & ${ }$-test $^{\mathrm{b}}$ \\
\hline Ife Brown $\times$ TVu1509 & $5.71 \pm 0.16$ & $3.99 \pm 0.25$ & $*$ \\
VITA 7 $\times$ TVu 1509 & $5.03 \pm 0.23$ & $3.70 \pm 0.26$ & $*$ \\
TVu 1509 $\times$ Sanzi & $3.30 \pm 0.25$ & $2.08 \pm 0.23$ & $*$ \\
Ife Brown $\times$ Sanzi & $5.65 \pm 0.16$ & $5.07 \pm 0.20$ & $*$ \\
VITA 7 $\times$ Sanzi & $5.90 \pm 0.27$ & $2.68 \pm 0.18$ & $*$ \\
VITA $\times$ Ife Brown 7 & $6.10 \pm 0.27$ & $5.86 \pm 0.25$ & ns \\
\hline
\end{tabular}

${ }^{\mathrm{a}}$ First named parent $=q$, Second named parent $=\hat{\sigma}$

b $\mathrm{F}_{1}$ means compared with $\mathrm{RF}_{1}$ means

* Significant at $1 \%$ probability levels by $t$-test; ns, not significant

\section{Progenies of crosses}

The frequency distributions for mean damage rating in the parental, $F_{1}, F_{2}$ and backcross generations are presented in Figs. 1-3. The parents used in this study did not represent genotypic extremes for resistance and susceptibility to flower thrips as the mean thrips damage rating was 4.25 for Sanzi and 5.60 for TVu 1509 while on the other hand, the mean damage rating was 7.4 and 7.99 for VITA 7 and Ife Brown, 
respectively. The observed frequency distributions of the two parents overlap for thrips damage rating (Figs. 1-3).

The mean damage rating of the $F_{1}$ hybrids of all the crosses were lower than that of $\mathrm{P}_{2}$ the susceptible parent and the mid parental values. The $\mathrm{RF}_{1}$ hybrids had mean thrips damage rating lower than that of $\mathrm{P}_{1}$ in the susceptible $\times$ resistant crosses, Ife Brown $\times \mathrm{TVu}$ 1509, VITA $7 \times$ TVu 1509 and VITA $7 \times$ Sanzi. In the resistant $\times$ resistant cross, the mean thrips damage rating for $\mathrm{F}_{1}$ hybrids was lower than that of $\mathrm{P}_{1}$. $\mathrm{BCP}_{1}$ and $\mathrm{BCP}_{2}$ plants were distributed across the range of
Fig. 1 Frequency distribution of flower bud thrips damage rating in six generations of the cowpea cross TVu $1509(\mathrm{R}) \times$ VITA $7(\mathrm{~S})$
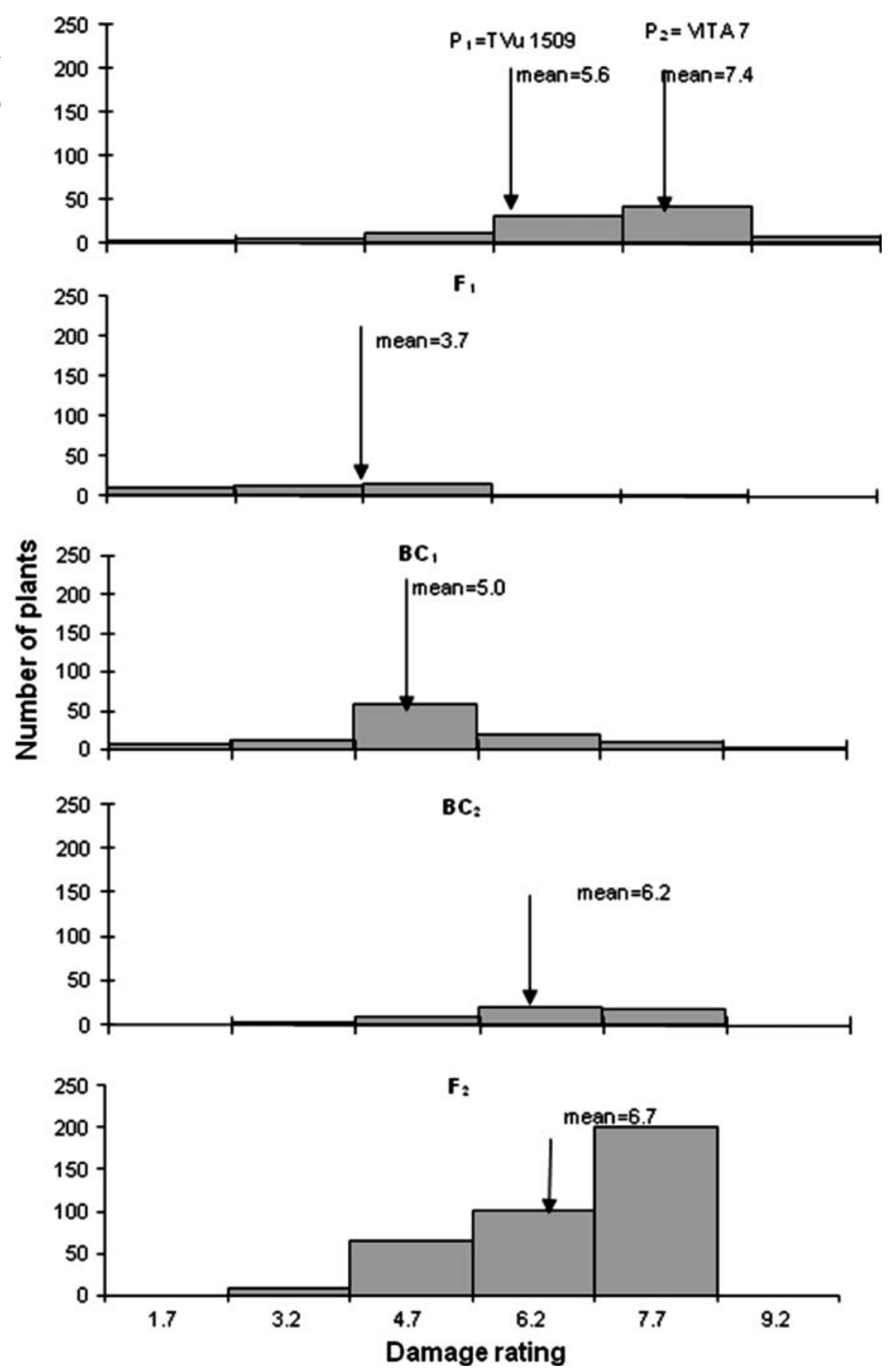
Fig. 2 Frequency distribution of flower bud thrips damage rating in six generations of the cowpea cross Sanzi (R) $\times$ VITA $7($ S)
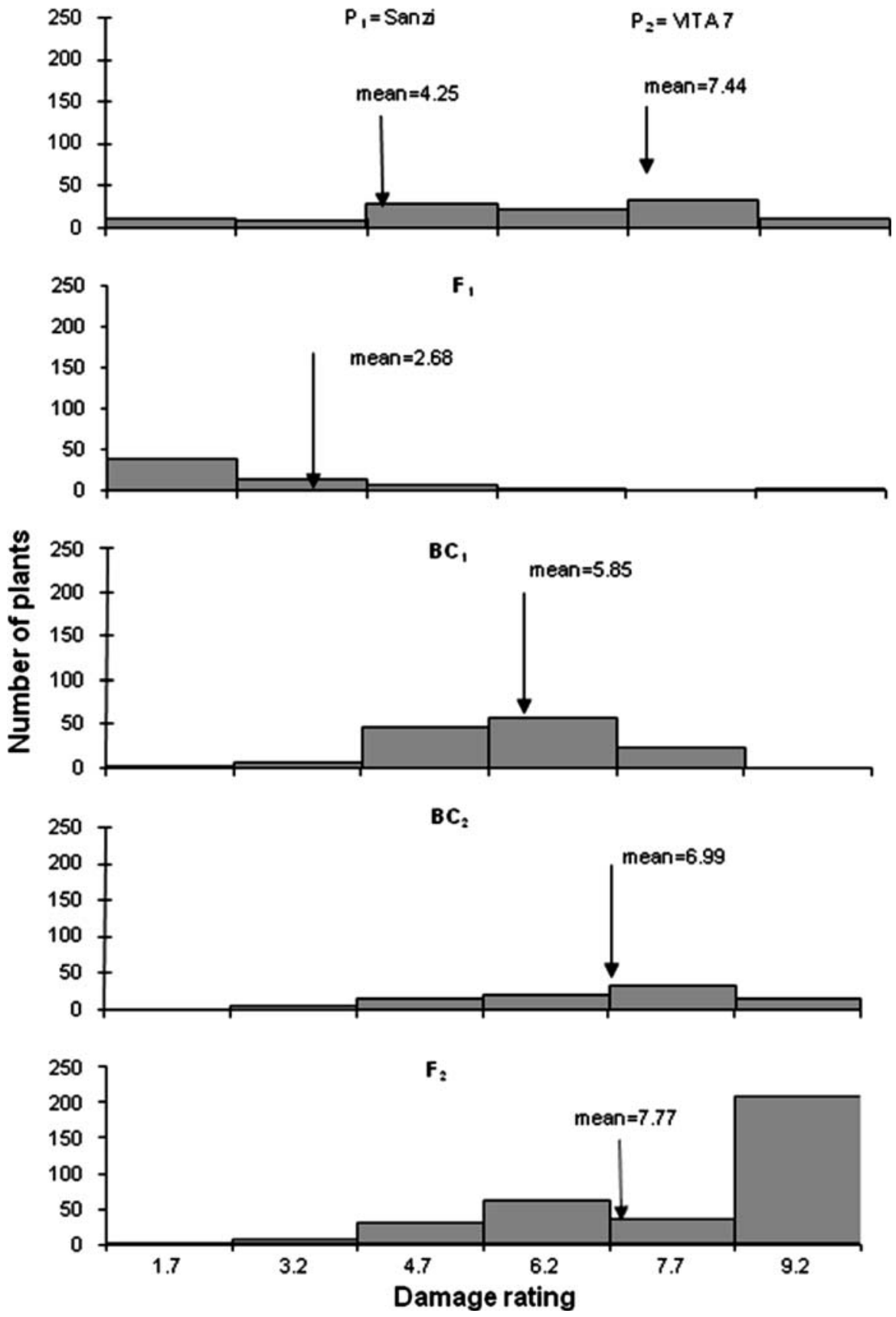

both parents, but were skewed towards the recurrent parents. In the cross between susceptible $\times$ susceptible the mean FTh damage ratings for both parents were not significantly different. $F_{1}$ mean $(6.1 \pm 0.27)$ was lower than the means of both parents. $F_{2}$ mean $(7.9 \pm 0.1)$ was similar to the means of both parents. On the other hand, in the resistant $\times$ resistant cross $($ Sanzi $\times$ TVu 1509), flower thrips damage rating data showed that the frequency distributions of the two parents overlap for thrips damage rating (Fig. 3). $\mathrm{P}_{1}$ mean was lower than $\mathrm{P}_{2}$ mean. $\mathrm{F}_{1}$ mean was lower than the means of both parents. $\mathrm{BCP}_{1}$ and $\mathrm{BCP}_{2}$ means were closer to $\mathrm{P}_{1}$. $\mathrm{BCP}_{1}$ and $\mathrm{BCP}_{2}$ plants were distributed across the range of both parents.

The $F_{2}$ generations resulting from resistant $\times$ susceptible crosses and resistant $\times$ resistant cross had 
Fig. 3 Frequency

distribution of flower bud thrips damage rating in six generations of the cowpea cross Sanzi $(\mathrm{R}) \times \mathrm{T} \mathrm{Vu}$ 1509 (R)
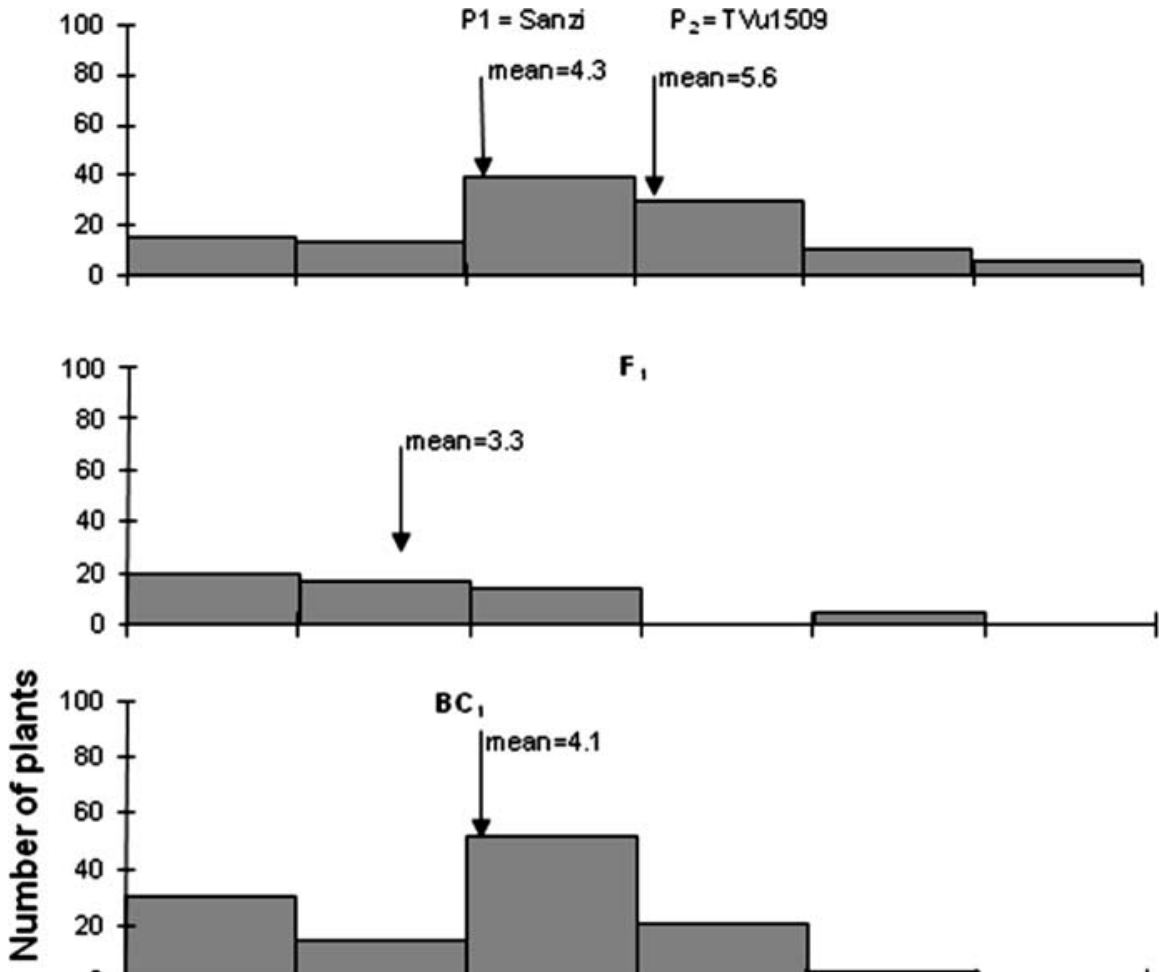

$B C_{1}$
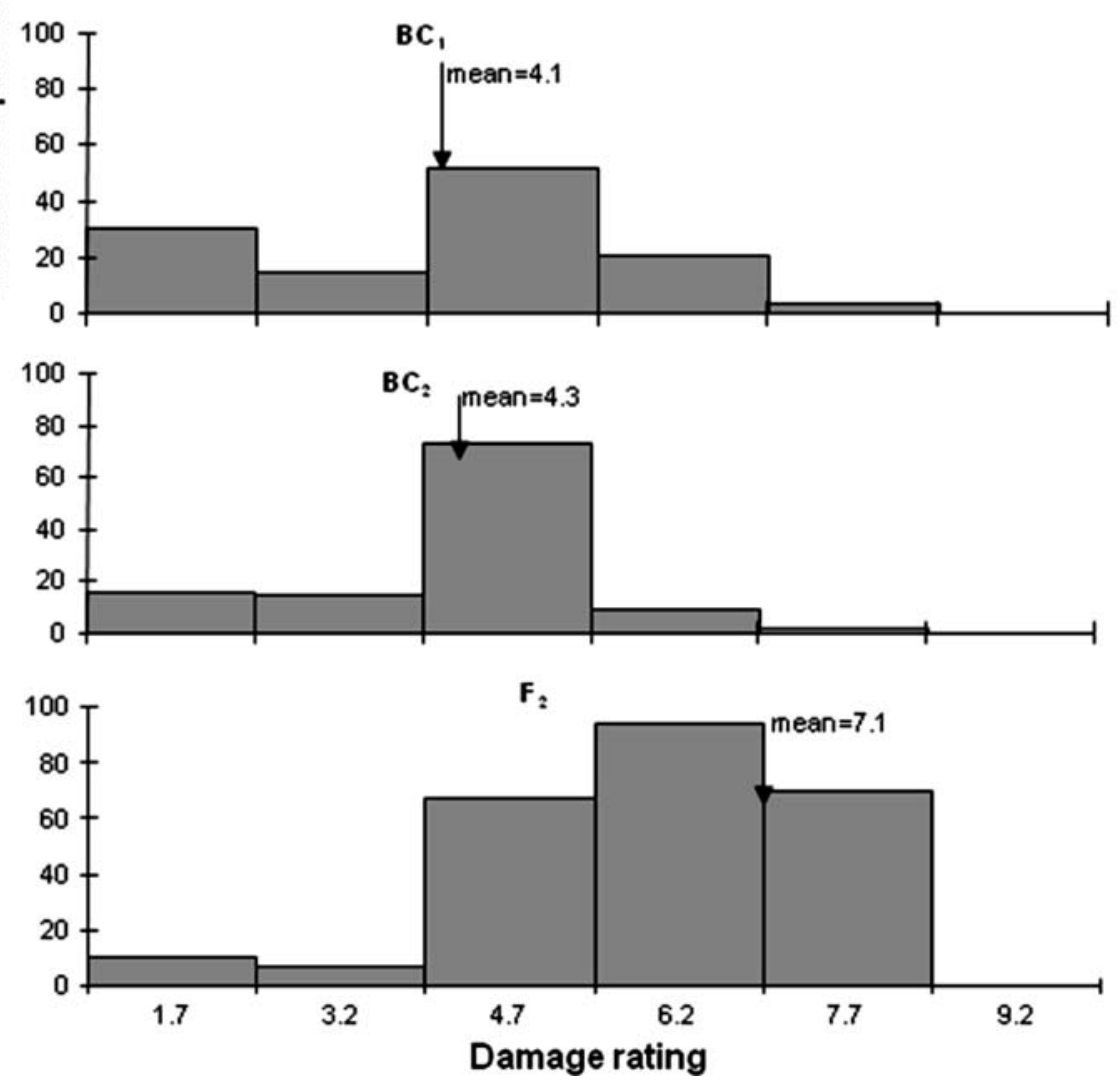

continuous distributions (Figs. 1-3). The $\mathrm{F}_{2}$ distributions ( $\mathrm{CV}$ ranged from $17.58 \%$ to $27.77 \%$ ) were in general, bimodal with modes in the 4.7 and 7.7 points. In the cross between resistant $\times$ resistant parents, the modes were in the 4.7 and 6.2 points. The relative magnitude of the modes varied in different crosses.
Estimates of gene effects for thrips damage rating and number of pods produced per plant

The nature of gene action involved in the resistance of cowpea to flower bud thrips was investigated by the analysis of generation means of six families (Table 3). The generation means analysis indicated that the 
additive-dominance model was not adequate to explain the gene action involved in the inheritance of resistance to FTh. Estimates of the six parameters for the various gene effects showed that additive effect was significant for resistance to FTh and number of pods per plant in all four families involving the resistant $\times$ susceptible crosses. Dominance (d) gene effect was highly significant in all the crosses. Additive $\times$ additive (aa), additive $\times$ dominance $(\mathrm{ad})$, and dominance $\times$ dominance $(\mathrm{dd})$ gene effects were highly significant in at least two of the five crosses (Table 3). In the resistant $\times$ susceptible cross, dominance gene effects were generally larger than the additive gene effects except in the cross Sanzi $\times$ Ife Brown where the additive gene effect made the most contribution. Dominance gene effects ranged from 1.57 to 3.92 , while additive gene effects ranged from 0.69 to 2.35 for resistance to FTh. Both additive and dominance gene effects were generally in the negative direction for thrips resistance score. Of the three types of epistatic effects (aa, ad and dd), the additive $\times$ additive (aa) gene effects were generally the most important in the characters studied and ranged from 1.00 to 2.35 for FTh damage rating and 0.53 to 1.41 for number of pods produced. Dominance, aa, ad, and dd gene effects were significant for thrips damage rating in resistant $\times$ resistant cross. Dominance and aa gene effects were more important than others in this cross. A similar result was observed in the number of mature pods produced per plant.

\section{Heritability and number of effective factors}

The minimum number of effective factors segregating in the $F_{2}$ generation of the resistant $\times$ susceptible crosses ranged from 3 to 5 . The minimum number of effective factors in resistant $\times$ resistant cross was 4 . Broad-sense heritability ranged from $56 \%$ to $73.36 \%$ while narrow-sense heritability ranged from $13.0 \%$ to $40.0 \%$ (Table 4).

\section{Allelic relationship of cowpea genes for resistance to M. sjostedti}

The mean damage scores of the two resistant parents were different (5.60 for TVu1509 and 4.25 for Sanzi). The $\mathrm{BCP}_{1}$ and $\mathrm{BCP}_{2}$ plants in the resistant $\times$ resistant cross were all resistant (Fig. 2). Some of the $F_{2}$ progenies of this cross were susceptible despite the fact that both parents are resistant. There were also some $F_{2}$ segregants that were more resistant to FTh than the two resistant parents. Segregation of resistance differed among progenies derived from TVu1509 and Sanzi. GMA showed that dominance gene effect was highly significant for the cross TVu1509 $\times$ Sanzi. These results suggest that some of the genes involved in the resistance to FTh in the two parents may be non-allelic (Table 5).

\section{Discussion}

This study showed that there was no significant difference between the number of days to first flower opening among the four cowpea genotypes tested. Thus, the resistance in Sanzi, and TVu 1509 cannot be explained by thrips infestation escape due to early flowering. However, while almost all flower buds dropped in the case of susceptible lines, many were retained and even formed pods in the resistant lines.
Table 4 Estimates of gene effects based on flower buds thrips damage rating (upper values) and their standard errors (bottom values) for five cowpea crosses

\begin{tabular}{lllcccc}
\hline Cross & $\mathrm{m}$ & $\mathrm{a}$ & $\mathrm{d}$ & $\mathrm{aa}$ & $\mathrm{ad}$ & $\mathrm{dd}$ \\
\hline TVu1509 × Ife Brown & $6.93^{* *}$ & $-0.69^{* *}$ & $-2.41^{* *}$ & $-1.33^{* *}$ & $0.50^{* *}$ & 0.05 \\
& 0.11 & 0.17 & 0.51 & 0.47 & 0.21 & 0.84 \\
TVu1509 × VITA 7 & $6.20^{* *}$ & $-1.25^{* *}$ & $-3.92^{* *}$ & $-2.35^{* *}$ & -0.33 & $2.87^{* *}$ \\
& 0.13 & 0.25 & 0.68 & 0.63 & 0.29 & 1.18 \\
Sanzi $\times$ TVu1509 & $5.99^{* *}$ & -0.16 & $-8.83^{* *}$ & $-7.21^{* *}$ & $0.51^{*}$ & $6.90^{* *}$ \\
& 0.14 & 0.21 & 0.63 & 0.58 & 0.26 & 0.06 \\
Sanzi $\times$ Ife Brown & $7.59^{* *}$ & $-2.35^{* *}$ & $1.57^{* *}$ & -1.00 & -0.18 & $-3.94 * *$ \\
& 0.13 & 0.20 & 0.62 & 0.56 & 0.25 & 1.03 \\
Sanzi $\times$ VITA 7 & $6.64 * *$ & $-1.00^{* *}$ & $-2.01 * *$ & $-1.81 * *$ & $0.58^{* *}$ & 0.00 \\
& 0.13 & 0.20 & 0.60 & 0.56 & 0.24 & 1.00 \\
\hline
\end{tabular}

* Significant at 5\% and ** significant at $1 \%$ probability levels 
Table 5 Estimates of heritability and number of effective factors controlling flower bud thrips resistance in five cowpea crosses

\begin{tabular}{llll}
\hline Cross & $\begin{array}{l}\text { \% Broad sense } \\
\text { heritability }\end{array}$ & $\begin{array}{l}\text { \% Narrow sense } \\
\text { heritability }\end{array}$ & $\begin{array}{l}\text { Number of } \\
\text { effective factors }\end{array}$ \\
\hline TVu 1509 $\times$ Ife Brown & 73.36 & 40.00 & 5 \\
TVu 1509 $\times$ VITA 7 & 64.00 & 13.00 & 4 \\
Sanzi $\times$ TVu 1509 & 56.00 & 29.00 & 4 \\
Sanzi $\times$ Ife Brown & 65.38 & 24.67 & 5 \\
Sanzi $\times$ VITA 7 & 56.01 & 31.65 & 3 \\
\hline
\end{tabular}

There were reciprocal differences among the $F_{1}$ progenies of the crosses. The occurrence of reciprocal differences between the $F_{1}$ means indicate the presence of cytoplasmic factors (Rusoke and Fatunla 1987; Singh and Hadley 1972; Fatunla and Badaru 1983). The results of reciprocal crosses consistently showed that the use of the resistant lines as female parent conferred superior resistance on the $F_{1}$ hybrid, suggesting that in a breeding program, to improve thrips resistance in cowpea, the resistant parent should be used as the maternal parent in crosses. The mean thrips damage rating of the $F_{1}$ plants was significantly lower than the mid parental values and was closer to the score obtained for the resistant parent indicating dominance of resistance over susceptibility. In this study, the frequency distributions of damage rating in the segregating populations revealed that, in most cases, the plants were distributed over the range of both parents. This suggests that more than two genes probably control the resistance to FTh.

The genetic analysis of generation means indicated that the additive-dominance model was not adequate to explain variation observed in the inheritance of resistance to thrips in cowpea. Generation means analysis provided estimates of the relative magnitudes of additive, dominance and epistatic gene effects. Estimates of the six parameters for the various gene effects showed that both the additive and dominance gene effects, contributed significantly to the inheritance of the traits studied, dominance gene effects were however larger than the additive gene effects. Additive $\times$ additive and dominance $\times$ dominance gene effects made major contributions to resistance to thrips. Broad sense heritability was relatively high, averaging $63 \%$. In breeding self-pollinated species, the plant breeder seeks to produce an improved pure line. The purpose of hybridization is therefore, to provide genetic variation on which selection can act. Epistasis is more important than dominance to the breeder of self-pollinating species, because dominance is broken by segregation following hybridization. Epistasis, on the other hand, does not depend on heterozygosity and can therefore permit more gene combinations than dominance. Because dominance and epistasis made large contributions to the inheritance of resistance to flower bud thrips in cowpea, rapid advances in breeding programme to incorporate this characteristic into commercial cowpea cultivars would best be made using a procedure, which emphasizes these gene effects. Since improved inbred lines are the desired product, selection should not be too severe in the early stages to allow for the desirable gene recombinations.

The minimum number of effective factors segregating for resistance ranged from 3 to 5 in $F_{2}$ progenies resulting from susceptible $\times$ resistant crosses and 4 in the resistant $\times$ resistant cross. These estimates indicate that resistance to flower bud thrips is oligogenic. This is contrary to an earlier report (highlights 1983) that two recessive genes controlled resistance to flower bud thrips damage in cowpea. It is instructive that cowpea line TVu 1509 used in this study still suffers some damage due to flower thrips. If only two recessive genes were responsible for resistance in TVu 1509 it is expected that individuals that inherit the two recessive genes should not show the typical thrips damage symptoms as was observed in the present study.

Apparent heterosis in the $F_{1}$ and transgressive segregation in the $F_{2}$, of the resistant $\times$ resistant cross may be explained by postulating the presence of both resistance and susceptible factors in the two resistant parents and the complementary action of these factors in their $F_{1}$ hybrids. GMA showed that dominance gene effect was highly significant for the cross between Sanzi and TVu 1509. The fact that the mean damage ratings of these two resistant parents were different (4.2 and 5.6, respectively), coupled with the highly significant dominance towards the better of the two parents, Sanzi, further shows that some of the genes in the two parents are non-allelic. 
Genetic diversity is a function of ancestry such that alleles contributed by two parents with different ancestry are more likely to vary from those contributed by parents with a common background. Sanzi is a land race from Ghana, while TVu 1509 is an improved germplasm line. There is therefore a high probability that they have different ancestries. TVu 1509 has been used as a donor for FTh resistance in breeding programmes at IITA (Singh 1977). Sanzi could also be incorporated into breeding programmes for resistance to FTh as an additional source of genes for resistance, which can be transferred into high yielding cultivars of cowpea.

\section{Conclusion}

The resistant maternal parent exhibited superior resistance in $F_{1}$ hybrids. Thus to improve resistance to FTh in cowpea, the resistant parent should be used as the maternal parent in crosses. The relatively high heritability shows that it should be possible to increase and diversify resistance of cowpea to flower bud thrips by accumulating different genes from the two sources of resistance.

Open Access This article is distributed under the terms of the Creative Commons Attribution Noncommercial License which permits any noncommercial use, distribution, and reproduction in any medium, provided the original author(s) and source are credited.

\section{References}

Afun JVK, Jackai LEN, Hodgson CJ (1991) Calender and monitored insecticide application for the control of cowpea pests. Crop Prot 10:363-370. doi:10.1016/S02612194(06)80025-6

Duke JA (1990) Introduction to food legumes. In: Singh SR (ed) Insect pests of tropical food legumes. Wiley, Chichester, pp 1-42

Fatunla T, Badaru K (1983) Inheritance of resistance to cowpea weavil (Callosobruchus maculatus Fabr.). J Agric Res Camb 101:423-426
Gamble EE (1962) Gene effects in corn (Zea mays 1.) 1. Separation and relative importance of gene effects for yield. Can J Plant Sci 42:339-348

Hayman BP (1958) The separation of epsistasis from additive and dominance variation in generation means. Heredity 12:371-380. doi:10.1038/hdy. 1958.36

IITA (1983) Research highlights. International Institute of Tropical Agriculture, Ibadan

Jackai LEN, Singh SR (1988) Screening techniques for host plant resistance to insect pests of cowpea. Trop Grain Legume Bull 35:2-18

Kang MS (1994) Applied quantitative genetics. 2477 Creekside Drive Baton Rouge, Louisiana, USA, pp 79-81

Lawrence PL, Frey KJ (1976) Inheritance of grain yield in oat species crosses Avena sativa $1 . \times$ A. sterilis L. Egypt $\mathrm{J}$ Genet Cytol 5:400-409

Mahmud K, Kramer H (1951) Segregation for yield, height, and maturity following a soya-bean cross. Agron J 43: 605-609

Mather K, Jinks JL (1982) Biometrical genetics. Cornell University Press, Ithaca, $396 \mathrm{pp}$

Quin FM (1997) Introduction. In: Singh BB, Mohan Raj DR, Dashiell KE, Jackai LEN (eds) Advances in cowpea research. Co-publication of International Institute of Tropical Agriculture (IITA) and Japan International Research Center for Agricultural Sciences (JIRCAS), IITA, Ibadan, pp ix-Xv

Rusoke DG, Fatunla T (1987) Inheritance of pod and seed resistance to the cowpea seed beetle (Callosobruchus maculatus Fabr.). J Agric Sci Camb 108:655-660

Singh SR (1977) Cowpea cultivars resistant to insect pests in world germplasm collection. Trop Grain Legume Bull 9:1-7

Singh SR, Allen DJ (1980) Pest, diseases, resistance and protection of Vigna unguiculata (L.) Walp. In: Summerffield RJ, Bunting HH (eds) Advances in legume science. Royal Botanical Gardens and Ministry of Agriculture, Fish and Food, London, pp 419-434

Singh L, Hadley H (1972) Maternal and cytoplasmic effects on seed protein content in Soybeans, Glycine $\max$ (L.) Merrill. Crop Sci 12:583-585

Singh BB, Chamblis OL, Sharma B (1997) Recent advances in cowpea breeding. In: Singh BB, Mohan Raj DR, Dashiell KE, Jackai LEN (eds) Advances in cowpea research. Copublication of International Institute of Tropical Agriculture (IITA) and Japan International Research Center for Agricultural Sciences (JIRCAS), IITA, Ibadan, pp 30-49

Terao T, Watanabe I, Matsunaga R, Hakoyama S, Singh BB (1997) Agro-physiological constraints in intercropped cowpea: an analysis. In: Singh BB, Mohan Raj DR, Dashiell KE, Jackai LEN (eds) Advances in cowpea Research. IITA/ JIRCAS Co-publication, IITA, Ibadan, pp 129-140 